\title{
Trends in Educational Research: A Content Analysis of the Studies Published in International Journal of Instruction
}

\author{
Eray Ĕgmir \\ Ph.D., Afyon Kocatepe University, Faculty of Education, Turkey, eegmir@aku.edu.tr
}

Cahit Erdem

Afyon Kocatepe University, School of Foreign Languages, Turkey, cerdem@aku.edu.tr

\section{Mehmet Koçyiğit}

Ph.D., Afyon Kocatepe University, School of Foreign Languages, Turkey, mkocyigit@aku.edu.tr Instruction [IJI] in the last ten years. This study is a qualitative, descriptive literature review study. The data was collected through document analysis, coded using constant comparison and analysed using content analysis. Frequencies and percentages were calculated. As IJI being an international, open access journal, the results of this analysis are expected to give a clue about the research trends in the field of education. Beyond this, within this study, the topics, the techniques of sampling, the methods of research, the statistical procedures and the countries in which the researches took place and some other variables were examined. The results showed that studies in the field of education mostly employ quantitative methods, purposive or random sampling techniques, and a sample size of below 500. Data collection tools mostly consist of scales and the data are mostly analyzed using descriptive statistics. Publishing studies from 35 different countries, IJI has a high level of internationality.

Keywords: International Journal of Instruction, research trends, content analysis, , trends in educational research, educational research

\section{INTRODUCTION}

Scientific research results are of high significance as they not only affect policies and implications in scientific areas but also form an empirical basis for implications and serve as a guide for implementers (Karadağ, 2009). Educational research which has been increasing in amount at a very rapid pace (Göktaş, Hasançebi et al. 2012; Karadağ, 2009; Keselman, et al, 1998; Onwuegbuzie \& Daniel 2003; Selçuk, Palanc1, Kandemir \& Dündar, 2014) can be considered in this sense as it is an important indicator of 
development level of educational system of a country (Gülmez \& Yavuz, 2016). Besides a variety of activities held in a field, scientific research reveals the production and accumulation of knowledge in that field (Yilmaz \& Altınkurt, 2012). Concordantly, educational research reveals the level of knowledge in educational context and particularly research regarding instruction affects the educational practice by leading the implications in the educational institutions and forming the basis for educational reforms.

While the proliferation in the number of studies in educational context shows the increasing focus on education, this also causes some problems. Results of studies on a topic may correspond to each other or they may contradict as studies are mostly carried out independently (Göktaş, Hasançebi et al. 2012). As each new study starts and develops with the examination of existing studies in a field (Gülbahar \& Alper, 2009), it is highly important to examine the studies and to evaluate the trends, methodologies, participants, research results and so on. In addition, examination of quantitative and qualitative properties of scientific studies enables identification of research trends and monitoring the development and change of a scientific discipline (Yıldız, Melekoğlu \& Paftal, 2016). Within this context, educational research should be examined periodically (Cohen, Manion \& Morrison, 2005; Selçuk et al. 2014; Yücedağ \& Erdoğan, 2011). To this end, educational researchers have started to examine published studies as in other fields (Karadağ, 2009). These kinds of studies which aim at synthesizing studies in educational field have gained popularity and vary from narrative studies to meta-analyses (Dunkin, 1996).

These review studies, either quantitative or qualitative, may focus on research results in a particular area or research process which includes methods, design and analysis issues (Keselman, et al. 1998). Many researchers carry out qualitative (content analyses) or quantitative (meta-analyses) reviews of literature (Onwuegbuzie \& Daniel, 2003). These studies reveals the profoundness and prevalence of a topic and overall picture of a field and contributes to the development of knowledge production systems and methods (Turan, Karadağ, Bektaş \& Yalçı, 2014). Review studies is mandatory for educational field as education is one of the fields that is affected in the first place by the change and development movements (Varışoğlu, Şahin \& Göktaş, 2013). Therefore, review of different realms of educational research contributes a lot to the field.

\section{REVIEW OF THE LITERATURE}

Recently, a number of content analysis and meta-analysis studies have been published reviewing educational research. These include studies on educational sciences in general (Adıgüzel \& Ergünay, 2012; Göktaş, Hasançebi et al. 2012; Keselman, et al. 1998), educational administration (Gülmez \& Yavuz, 2016; Karadağ, 2015; Turan et al. 2014), educational technology (Göktaş, Küçük, et al. 2012; Gülbahar \& Alper, 2009; Hrastinski \& Keller, 2007; Hwang \&Tsai, 2011; Küçük, Aydemir, Yıldırım, Arpacık \& Göktaş, 2013; Şimşek, et al., 2008), curriculum and instruction (Ozan \& Köse, 2014), primary school teacher education (Kü̧̈ükoğlu \& Ozan, 2013), special education (Yıldız et al. 2016), language education (Varışoğlu et al. 2013), teacher education (Yücel-Toy, 2015), mathematics education (Yücedağ \& Erdoğan, 2011), environmental education 
(Erdoğan, Marcinkowski \& Ok, 2009), preschool education (Yılmaz \& Altınkurt, 2012) and science education (Tsai \& Wen, 2005). Content analysis studies in this sense form the basis of comparative studies and puts forth the research trends (Cohen et al. 2005). Reviewing articles in academic journals is instrumental in gaining awareness regarding the field and monitoring the change (Gülmez \& Yavuz, 2016). In addition, examining international academic journals with this aim helps to reveal trends and changes at the international level rather than limiting the review to research in a single country.

Journals publishing educational research and being indexed in international educational indexes have increased in great numbers in Turkey recently (Y1lmaz \& Altınkurt, 2012). International Journal of Instruction is one of these journals. This journal, which was founded in 2008 in Turkey aims to publish high quality studies in the areas of instruction, learning, teaching, curriculum development, learning environments, teacher education, educational technology, educational developments and it is indexed in various indexes (e-iji.net). As researchers from around the world publish their articles in this journal, a content analysis of these articles from 2008 to 2017 would provide significant data regarding the articles in terms of topics, models, design, data collection instruments, analysis techniques, sampling methods, participants and the country in which the study is conducted. Therefore, this study aims to analyze the articles published in International Journal of Instruction [IJI] from 2008 to 2017 using content analysis method.

\section{RESEARCH QUESTIONS}

RQ1: What is the distribution of the articles in IJI according to the countries the study is conducted in?

RQ2: What is the distribution of the articles in IJI according to the number of authors?

RQ3: What is the distribution of the topics studied in the articles in IJI?

RQ4: What is the distribution of the articles according to the research methods and design?

RQ5: What is the distribution of the articles according to the data collection techniques?

RQ6: What is the distribution of the data analysis techniques used in the articles in IJI?

RQ7: What is the distribution of the articles in IJI according to the sampling techniques and sample sizes?

RQ8: What is the distribution of the articles in IJI according to the sample types?

\section{METHOD}

This is a qualitative, descriptive literature review study. Literature reviews, including research syntheses and meta-analyses, are critical evaluations of material that has already been published (APA, 2010, p. 10). For the reliability and validity of the study the coding of the data was carried out using constant comparison method and crosscheck by the researchers. Constant comparison is an inductive data analysis procedure in which the researcher generates and connects categories by comparing incidents in the data to other incidents, incidents to categories, and categories to other categories (Creswell, 2012). Although there was a rubric consisting of pre-defined categories, while coding the data, new categories could arise deriving from the data analyzed. After the coding has finished, the completed rubric was cross-checked by the researchers. 
Beyond these methods, as IJI being an open access journal, the archive of the journal is open to anyone making the results of this study reviewable.

\section{Sample}

All the issues of IJI in the last ten years (from 2008 to March 2017) were included the study using the purposive sampling method of qualitative sampling methods. Purposive sampling indicates exactly what its name suggests in which members of a sample are chosen with a purpose to represent a location or type in relation to a key criterion. Two main reasons for this are (i) to ensure that all the key constituencies of relevance to the subject matter are covered, (ii) to ensure that, within key criteria, some diversity is included so that the impact of the characteristic concerned can be explored (Ritchie, Lewis \& Elam, 2003).

\section{Data collection tools}

The data was collected using document analysis method which is a systematic procedure for reviewing or evaluating documents - both printed and electronic (computer-based and Internet-transmitted) material (Bowen, 2009 p. 27) and with a rubric form developed by the researchers. The form consisted of the categories of date, country, number of authors, subject, theme, model/design, sample, sampling technique, sample size, data collection and data analysis. While developing the form, similar studies in the field were analyzed, each researcher prepared a rubric, all the forms were put together and the final rubric was prepared as a combination of these forms.

\section{Data Analysis}

While analyzing the data, content analysis was used. The data collected using document analysis technique were coded by the researchers using the rubric developed beforehand through constant comparison, and were analyzed using content analysis. Content analysis is used to refer to any qualitative data reduction and sense-making effort attempting to identify core consistencies and meanings which are often called patterns or themes (Patton, 2002) or categories (Merriam, 2013). For each category, frequencies and percentages were calculated.

\section{Procedure}

First, the data collection tool was developed. Then, all the issues of IJI (between 1998March 2017) were downloaded. Each article in every issue was analyzed and the data were coded using the rubric. While analyzing the articles, some new categories emerged and these categories were added to rubric and the analysis phase restarted. After this phase, the coded data were cross-checked by the researchers. When the rubric took its final form, frequencies and percentages for each category were calculated and presented in the findings.

\section{FINDINGS}

The first finding is about research question one. The distribution of the articles published according to the variable of country where the studies were conducted is given in Table 1. 
Table 1

Distribution according to the country where the study took place

\begin{tabular}{|c|c|c|c|c|c|}
\hline Country & $f$ & $\%$ & Germany & 1 & 0,5 \\
\hline \multirow{2}{*}{ Turkey } & \multirow{2}{*}{50} & 25 & Taiwan & 1 & 0,5 \\
\hline & & 3 & Belgium & 1 & 0,5 \\
\hline \multirow{2}{*}{ The USA } & \multirow{2}{*}{31} & 15 & North Cyprus & 1 & 0,5 \\
\hline & & 7 & Kuwait & 1 & 0,5 \\
\hline \multirow{2}{*}{ Malaysia } & \multirow{2}{*}{23} & 11 & Egypt & 1 & 0,5 \\
\hline & & 6 & Tanzania & 1 & 0,5 \\
\hline Iran & 16 & 8,1 & Scotland & 1 & 0,5 \\
\hline Indonesia & 8 & 4 & Czech Republic & 1 & 0,5 \\
\hline \multirow{2}{*}{ Oman } & \multirow{2}{*}{7} & 3,5 & Greece & 1 & 0,5 \\
\hline & & 5 & Japan & 1 & 0,5 \\
\hline \multirow{2}{*}{ India } & \multirow{2}{*}{7} & 3,5 & Morocco & 1 & 0,5 \\
\hline & & 5 & Sudan & 1 & 0,5 \\
\hline Saudi Arabia & 6 & 3 & China & 1 & 0,5 \\
\hline Pakistan & 5 & 2,5 & Kazakhstan & 1 & 0,5 \\
\hline Ethiopia & 4 & 2 & Hong Kong & 1 & 0,5 \\
\hline Nigeria & 4 & 2 & Canada+Spain & 1 & 0,5 \\
\hline Zimbabwe & 3 & 1,5 & Turkey+Germany & 1 & 0,5 \\
\hline Thailand & 3 & 1,5 & Malaysia+Bangladesh+ & & \\
\hline Spain & 2 & 1 & Pakistan+Yemen+Kuwait & 1 & 0,5 \\
\hline Bangladesh & 2 & 1 & +Saudi Arabia & & \\
\hline Canada & 2 & 1 & TOTAI & 19 & 100 \\
\hline Vietnam & 2 & 1 & TUTAL & 7 & 100 \\
\hline England & 1 & 0,5 & & & \\
\hline
\end{tabular}

As can be seen in Table 1, articles from a total of 35 different countries has been published in IJI. The most frequent countries are Turkey, USA, Malaysia, Iran, Indonesia, Oman, India, Saudi Arabia, Pakistan and Ethiopia. From England to Hong Kong, 17 countries have at least one article published. A study was conducted both in Canada and in Spain and a study was conducted both in Turkey and in Germany. One of the studies was conducted in six different countries.

The second finding of the study is about research question two. The distribution of the number of authors of the articles is given in Table 2 .

Table 2

The distribution of number of authors

\begin{tabular}{lll}
\hline Number of authors & $f$ & $\%$ \\
\hline 1 & 73 & 37 \\
2 & 65 & 32,9 \\
3 & 38 & 19,2 \\
$3+$ & 21 & 10,6 \\
TOTAL & 197 & 100 \\
\hline
\end{tabular}

It can be seen from table 2 that, most of the articles have one or two authors. The total number of three or more author articles is $59(29.8 \%) .73(37 \%)$ of the articles are one authored and 65 (32.9\%) of the articles are 2 authored.

The third finding of the study is about research question three. The distribution of the topics studied in articles are given in Table 3. 
Table 3

The distribution of the topics studied in articles

\begin{tabular}{|c|c|c|c|}
\hline THEME & Subject & $f$ & $\%$ \\
\hline \multirow{25}{*}{ Teaching and Learning } & Language learning/teaching & 35 & 13,9 \\
\hline & Online learning/teaching & 13 & 5,1 \\
\hline & Computer assisted instruction & 7 & 2,7 \\
\hline & Reading (engagement/comprehension) & 7 & 2,7 \\
\hline & Cooperative/Collaborative learning & 7 & 2,7 \\
\hline & Project based learning & 5 & 1,9 \\
\hline & Classroom management & 5 & 1,9 \\
\hline & Inclusive education & 5 & 1,9 \\
\hline & Constructivist approach & 4 & 1,5 \\
\hline & Distance learning & 4 & 1,5 \\
\hline & Assessment practices & 4 & 1,5 \\
\hline & Technology integration & 4 & 1,5 \\
\hline & Instructional materials & 3 & 1,1 \\
\hline & Instructional design & 3 & 1,1 \\
\hline & Effect of cultural differences & 3 & 1,1 \\
\hline & Drama education & 2 & 0,7 \\
\hline & Counselling and guidance services & 2 & 0,7 \\
\hline & English as a medium of instruction & 2 & 0,7 \\
\hline & Learning strategies/approach & 2 & 0,7 \\
\hline & Academic ability/development & 2 & 0,7 \\
\hline & Pre-school education & 2 & 0,7 \\
\hline & Learning environment & 2 & 0,7 \\
\hline & Inquiry based learning & 2 & 0,7 \\
\hline & Educational management & 2 & 0,7 \\
\hline & Subtotal & 175 & 69,7 \\
\hline \multirow{3}{*}{ Teacher education } & No themes & 8 & 3,1 \\
\hline & Competency of teachers & 3 & 1,1 \\
\hline & Subtotal & 19 & 7,5 \\
\hline \multirow{5}{*}{ Skills } & Critical thinking & 4 & 1,5 \\
\hline & Thinking/Reasoning skills & 3 & 1,1 \\
\hline & Spatial ability & 2 & 0,7 \\
\hline & Writing skills & 2 & 0,7 \\
\hline & Subtotal & 19 & 7,5 \\
\hline \multirow{4}{*}{ Curriculum } & Curriculum evaluation & 4 & 1,5 \\
\hline & Curriculum design & 4 & 1,5 \\
\hline & Content development & 2 & 0,7 \\
\hline & Subtotal & 15 & 5,9 \\
\hline \multirow{9}{*}{ Teachers } & Laptop ownership and use & 1 & 0,3 \\
\hline & Teacher reflection & 1 & 0,3 \\
\hline & Seniority & 1 & 0,3 \\
\hline & Teacher autonomy & 1 & 0,3 \\
\hline & Teacher attention & 1 & 0,3 \\
\hline & Content knowledge & 1 & 0,3 \\
\hline & Teacher retention & 1 & 0,3 \\
\hline & Teacher leadership & 1 & 0,3 \\
\hline & Subtotal & 8 & 3,1 \\
\hline \multirow[t]{2}{*}{$I C T$} & & 5 & 1,9 \\
\hline & Classroom assessment environment & 1 & 0,3 \\
\hline \multirow[t]{2}{*}{ Scale development } & 21 th century skills & 1 & 0,3 \\
\hline & Scientific inquiry & 1 & 0,3 \\
\hline
\end{tabular}

International Journal of Instruction, July $2017 \bullet$ Vol.10, No.3 


\begin{tabular}{llll}
\hline & Subtotal & 3 & 1,1 \\
\hline Ethic/Ethics of responsibility & 2 & 0,7 \\
\hline Comparative education & 2 & 0,7 \\
\hline Non-formal education & 1 & 0,3 \\
\hline Employability & 1 & 0,3 \\
\hline School dropouts & 1 & 0,3 \\
\hline TOTAL & 251 & 100 \\
\hline
\end{tabular}

As it can be seen from table 3 , most of the studies grouped under the theme of teaching and learning ( $\mathrm{f}=175,69.7 \%)$. Under this theme, the most studied subject was language teaching and learning $(\mathrm{f}=35,13.9 \%)$. Subjects studied only once in this theme are not given in the table. These include writing instruction, 7E instructional model, tutoring, academic leadership, content preference, career adaptability, task-based teaching, flipped classroom, peer support, discovery learning, scenario-based learning, scaffolding, listening comprehension, service education, experiential learning, metacognitive strategies, emotional variables, learner autonomy, recall performance, tool assessment, questioning strategies, authentic learning, physical education, bullying behavior, evaluation of textbooks, self-concept, learner variables, science achievement, learning from text, role identity, teaching efficiency, conceptions of competency, instructional problems, instructional practices, motivational orientations, teaching approach, epistemological belief, bilingual learners, early literacy, citizenship education, reflective practices, parental attachment, effects of humor, school effectiveness, differentiated instruction, concept attainment model, religious education, technology engagement.

Other themes that the studies grouped under are teacher education $(\mathrm{f}=19,7.5 \%)$ and skills $(\mathrm{f}=19,7.5 \%)$. The most studied subject under the skills theme is critical thinking $(\mathrm{f}=4,1.5 \%) .15$ of the studies (\%5.9) are grouped under the theme of curriculum. The most studied subjects of this theme are curriculum evaluation $(\mathrm{f}=4,1.5 \%)$ and curriculum design $(\mathrm{f}=4,1.5 \%)$. The theme of teachers has eight studies under it $(3.1 \%)$, and ICT has five $(1.9 \%)$. There are three studies $(1.1 \%)$ under the theme of scale development while the themes of ethics and comparative education have two studies each $(0.7 \%)$. Non-formal education, employability and school dropouts themes have one study $(0.3 \%)$ each. A total of 251 subjects were studied by the 197 research studies published in IJI as some articles dealt with more than one subject at a time.

The fourth finding of the study is about research question four. The articles showed a distribution among three methods and 16 research designs. All the articles were grouped according to the method and the research design under that method (Table 4). 
Table 4

Distribution of the articles according to research methods and design

\begin{tabular}{lllll}
\hline Research Methods & Research design & $f$ & $\%$ \\
\hline \multirow{4}{*}{ Quantitative } & Descriptive survey & 70 & 35,5 \\
& Experimental study & 32 & 16,2 \\
& Correlational survey & 10 & 5 \\
& SEM & 2 & 1 \\
& & 1 & 0,5 \\
& & 6 & 3 \\
& & Other & 121 & 61,4 \\
\hline & Subtotal & 22 & 11,1 \\
& & Case study & 8 & 4 \\
& & Action research & 4 & 2 \\
& & Phenomenological method & 2 & 1 \\
\cline { 2 - 6 } Qualitative & Grounded theory & 7 & 3,5 \\
& & Conceptional study & 7 & 3,5 \\
& & Theoretical analysis (Literature & 2 & 1 \\
& & review)/Document analysis & 1 & 0,5 \\
& Non-interactive & Discourse analysis & 1 & 0,5 \\
\hline & Historical review & 16 & 8,1 \\
& & Meta-analysis & 70 & 35,5 \\
\hline Mixed method & Other (interpretative and exploratory studies) & 6 & 3 \\
\hline TOTAL & Subtotal & 197 & 100 \\
\hline
\end{tabular}

As can be seen from Table 4, $121(61.4 \%)$ of the studies employed a quantitative method. Of all the research designs under the category of quantitative method, descriptive survey is the most used research design $(\mathrm{f}=70,35.5 \%)$. It can be seen that just the number of descriptive survey studies is equal to the total of qualitative studies. 70 of the studies $(35.5 \%)$ are qualitative studies. Under the category of qualitative method, the most popular research design seems to be case study $(\mathrm{f}=22,11.1 \%)$. Six $(3 \%)$ of the articles used a mixed method.

The fifth finding of the study is about research question five. Each article used different data collection techniques and some of them used more than one at a time. The distribution of the articles according to the data collection technique is given in Table 5.

Table 5

Distribution of the articles according to the data collection technique

\begin{tabular}{lll}
\hline Data Collection Technique & $f$ & $\%$ \\
\hline Scale/Questionnaire & 90 & 36,1 \\
Interview & 50 & 20 \\
Documents & 36 & 14,4 \\
Observation & 24 & 9,6 \\
Achievement test & 24 & 9,6 \\
Ability/Personal test & 21 & 8,4 \\
Alternative/Complementary Evaluation & 4 & 1,6 \\
TOTAL & 249 & 100 \\
\hline
\end{tabular}

The most used data collection techniques are scales/questionnaires $(\mathrm{f}=90,36.1 \%)$ and interviews $(\mathrm{f}=50,20 \%)$. Other techniques used for data collection are documents $(\mathrm{f}=36$, 
$14.4 \%)$, observation $(\mathrm{f}=24,9.6 \%)$, achievement test $(\mathrm{f}=24,9.6 \%)$, ability/personal test $(\mathrm{f}=21,8.4 \%)$ and alternative/complementary evaluation $(\mathrm{f}=4,1.6 \%)$ respectively.

The sixth finding of the study is about research question six. All the 197 articles reported to have used different data analysis techniques at different stages or to test different hypotheses of the studies.

Table 6

Distribution of the data analysis techniques used in the articles

\begin{tabular}{lll}
\hline Data Analysis Technique & $f$ & $\%$ \\
\hline Descriptive statistics (f, \%, X, S) & 103 & 30,3 \\
t-test & 50 & 14,7 \\
ANOVA/ANCOVA & 39 & 11,5 \\
Descriptive Analysis (qual) & 39 & 11,5 \\
Correlation & 31 & 9,1 \\
Content Analysis (qual) & 27 & 7,9 \\
Chi-Square & 11 & 3,2 \\
Regression & 10 & 2,9 \\
\hline Data Analysis Technique & $f$ & $\%$ \\
\hline Other & 7 & 2 \\
Multiple Regression & 6 & 1,7 \\
Kruskal Wallis & 6 & 1,7 \\
Factor Analysis & 3 & 0,8 \\
MANOVA & 3 & 0,8 \\
Mann-Whitney U & 3 & 0,8 \\
SEM & 1 & 0,2 \\
TOTAL & 339 & 100 \\
\hline
\end{tabular}

As it can be seen from Table 6, nearly one third of the all analysis techniques used are descriptive studies ( $\mathrm{f}=103,30.3 \%)$. Of the qualitative data analysis techniques, descriptive analysis $(\mathrm{f}=39,11.5 \%)$ is more popular than content analysis $(\mathrm{f}=27,7.9 \%)$. Mostly used quantitative hypothesis tests are t-test $(\mathrm{f}=50,14.7 \%)$, ANOVA/ANCOVA $(\mathrm{f}=39,11.5 \%)$ and correlation tests $(\mathrm{f}=31,9.1 \%)$. The least used analysis is SEM $(\mathrm{f}=1,0.2 \%)$.

The seventh finding of the study is about research question seven. The distribution of the articles according to sampling techniques and sample sizes are given in Table 7.

Table 7

Distribution of the articles according to sampling techniques and sample sizes

\begin{tabular}{lll}
\hline Sampling Technique & $f$ & $\%$ \\
\hline Purposive & 32 & 32,9 \\
Random & 28 & 28,8 \\
Convenience/Availability & 15 & 15,4 \\
Stratified & 8 & 8,2 \\
Clustered & 4 & 4,1 \\
No sampling & 3 & 3 \\
Proportional & 2 & 2 \\
Criterion & 2 & 2 \\
Snowball sampling & 2 & 2 \\
Maximum variety & 1 & 1 \\
TOTAL & 97 & 100 \\
\hline
\end{tabular}

\begin{tabular}{lll}
\hline Sample Size & $f$ & $\%$ \\
\hline $1-100$ & 94 & 55,9 \\
$101-200$ & 29 & 17,2 \\
$201-300$ & 11 & 6,5 \\
$301-400$ & 9 & 5,3 \\
$401-500$ & 7 & 4,1 \\
$501-600$ & 3 & 1,7 \\
$601-700$ & 5 & 2,9 \\
$701-800$ & - & - \\
$801-900$ & 2 & 1,1 \\
$901-1000$ & 2 & 1,1 \\
$1000+$ & 6 & 3,5 \\
TOTAL & 168 & 100 \\
\hline
\end{tabular}

As it can be seen from Table 7, purposive ( $\mathrm{f}=32,32.9 \%)$, random $(\mathrm{f}=28,28.8 \%$ ) and convenience/availability $(\mathrm{f}=15,15.4 \%)$ are the most preferred sampling techniques 
respectively. Maximum variety sampling is the least preferred one $(\mathrm{f}=1,1 \%)$. Of the articles that used a countable sample $(n=168), 94$ of them $(\% 55.9)$ used a sample between 1 and 100. Most of the articles reported a sample size below $301 \quad(\mathrm{f}=134$, $79.6 \%) .12$ of the studies (6.8\%) used a sample between 501 and 1000 and six of the studies $(3.5 \%)$ used a sample more than 1000.

The eighth finding of the study is about research question eight. The distribution of the articles according to the participants is given in Table 8 .

Table 8

Distribution of the articles according to the sample types

\begin{tabular}{llll}
\hline Sample & & $f$ & $\%$ \\
\hline & Pre-School & 2 & 0,9 \\
Students & Elementary & 10 & 4,5 \\
& Secondary & 29 & 13 \\
& High School & 11 & 4,9 \\
& Undergraduate & 44 & 19,8 \\
& Graduate & 6 & 2,7 \\
& Teacher Candidates & 23 & 10,3 \\
& Subtotal & 133 & 59,9 \\
\hline Sample & & & $\%$ \\
\hline & & $f$ & 0,9 \\
Teachers & & 2 & 9,4 \\
& Pre-School & 21 & 6,7 \\
Earents & Elementary & 15 & 3,1 \\
TOTAL & Secondary & 7 & 1,3 \\
& High School & 3 & 21,6 \\
\hline & NA & 48 & 7,6 \\
Faculty member-Lecturer & Subtotal & 17 & 4,5 \\
& & 10 & 4 \\
& & 9 & 2,2 \\
& & 5 & 100 \\
\hline
\end{tabular}

As seen in Table 8 , most of the studies $(\mathrm{f}=133,59.9 \%)$ were carried out with student participants differing from k-12 to graduates. 48 of the studies $(21.6 \%)$ were carried out on teachers of different grade levels, 17 (7.6\%) of them on faculty members, $10(4.5 \%)$ on other, nine $(4 \%)$ on school administrators and five $(2.2 \%)$ of them on parents. As a study can employ more than one sample, a total of 222 samples were studied on by 197 articles.

\section{CONCLUSION AND DISCUSSION}

This study presents an analysis of the articles published in International Journal of Instruction from 2008 to 2017. IJI was chosen for this kind of study because it is an international journal and it has been active for a decade now in the field of education. The results of the study reveal the big picture of the studies published in IJI and will surely show a glimpse of the research tendencies in the field of educational sciences, especially instruction as being the name of the journal. Indeed, being able to see the whole picture of research tendencies in the field requires studying on more than one 
journal, which is a limitation of this study. However, when the studies similar to this one are taken into consideration altogether, the results would make more sense.

The findings reveal that, the distribution of the number of authors in IJI is similar to the other studies in the literature. The analysis of the distribution of the number of authors reveal that almost $70 \%$ of the articles are published by one author or two authors $(37 \%$ and $32.9 \%$ respectively). This case is prevalent in the literature. For instance, Yildiz et al. (2006) categorized research studies on special education in Turkey and found out that the majority of the articles were written by single authors $(59,29 \%)$ and the rest were mainly by two authors $(33,63 \%)$. The studies on curriculum and instruction from 2007 to 2011 (Ozan \& Köse, 2014), articles published in the journal of Educational Administration: Theory and Practice from 2003 to 2013 (Turan et al, 2014), and articles on Turkish education (Varışoğlu et al. 2013) were mainly carried out by a single author or two authors.

The analysis reveals that the articles published in IJI mainly used quantitative methods $(61.4 \%)$. There are similar findings in other reviews. It is found out in the study by Göktaş, Küçük et al. (2012) that, Turkey-addressed articles on educational technology published in international journals prominently used quantitative methods. Göktaş, Hasançebi et al. (2012) reviewed 19 Turkish educational research journals and reached a similar finding. Bozkaya, Aydin \& Kumtepe (2012) found out that $61.9 \%$ of the articles published in TOJET from 2008 to 2011 used quantitative methods, which is very close to the finding in this study. Y1lmaz \& Altınkurt (2012) reviewed 17 journals with respect to preschool education and identified that $76 \%$ of the studies were quantitative. Only $4 \%$ of these studies used mixed method. Hrastinski \& Keller (2007) reviewed 660 articles on educational technology and the percentages of quantitative, qualitative and mixed methods are $51 \%, 25 \%$ and $24 \%$ respectively. The dominance of quantitative methods in the articles are also found out in the reviews by Ozan \& Köse (2014); Küçükoğlu \& Ozan (2013); Selçuk et al. (2014); Turan et al. (2014); Varışoğlu et al. (2013); Yildiz et al. (2016). Although quantitative methods have some advantages, there is need for studies using more qualitative and mixed methods. Hoskyn \& Zegwaard (2015) points out that there has been an increase in the number of articles using qualitative and mixed methods in Asia-Pasific Journal of Cooperative Education. In parallel with this, a review by Gülbahar \& Alper (2009) on instructional technologies in five journals revealed that $47 \%$ of them used quantitative methods while $45 \%$ of them used qualitative methods in the years from 2005 to 2007 . Besides, $8 \%$ of them used mixed method while this percentage is only $3 \%$ in this study. Gülmez \& Yavuz (2016) also pointed out that qualitative studies had an impetus in the last years in the literature of educational leadership and management. Yücel-Toy (2015) states that although quantitative studies are dominant, there has been an increase in the number of qualitative and mixed studies since 2000. These findings unearth the need for more qualitative and mixed studies.

In the studies in IJI, the biggest group of participants are undergraduate students and teacher candidates $(30.1 \%)$. Yücedağ \& Erdoğan (2011) found out in their review on mathematics education studies that the participants of the $35 \%$ of the studies they 
analyzed were teacher candidates. The relatively high percentage of participants attending higher education is similar in other studies. Hwang \& Tsai (2011) reviewed articles on mobile and ubiquitous learning and found out that higher education sample is the most selected one (58\%). Findings of Küçük et al.'s (2013) review are also in the same fashion. Articles on educational technology published in 94 journals most frequently used teacher candidates $(31.1 \%)$ and other undergraduate students (17.3\%). In addition, the reviews by Ozan \& Köse (2014); Göktaş, Hasançebi et al. (2012), Selçuk et al. (2014), Şimşek et al. (2008) also reveal that the most common participants are undergraduate students and teachers.

The most frequent sampling techniques used in the articles published in IJI are purposive, random, convenience, stratified and cluster sampling. Similarly, Küçük et al.'s (2013) review revealed that the most frequent sampling techniques in educational technology are purposive, convenience, random and whole population types. Purposive, convenience and random sampling methods were found as the mostly resorted methods also in the reviews by Selçuk et al. (2014); Varışoğlu et al. (2013); Göktaş, Hasançebi et al. (2012).

The sample size in $89 \%$ of the articles (150 out of 168 ) published in IJI were below 500 . Similarly, Gülbahar \& Alper (2009) analyzed articles on instructional technologies in five journals and found out that the sample size in $89 \%$ of these articles (80 out of 89) were below 500. In addition, 55.9\% of the articles published in IJI were below 100. This finding is also in consistence with the findings of other reviews. For instance, the majority of the articles reviewed by Turan et al. (2014); Ozan \& Köse (2014); Varışoğlu et al. (2013); Küçükoğlu \& Ozan (2013); Göktaş, Hasançebi et al. (2012) had 100 or less participants.

The data collection technique used the most in the studies published in IJI is scale/questionnaire (36.1\%). This percentage is quite close to the findings in Gülbahar $\&$ Alper (2009). They found out that $34 \%$ of the studies on instructional technologies in five journals used scales/questionnaires. The review of the studies on preschool education in 17 journals by Y1lmaz \& Altınkurt (2012) revealed that 52\% of the studies used scales/questionnaires. Selçuk et al. (2014); Göktaş, Hasançebi et al. (2012) found that researchers mostly used attitude, perception and personality tests and Ozan \& Köse (2014); Küçükoğlu \& Ozan (2013); Şimşek et al. (2008) found out that the most common data collection tools are questionnaires and Likert-type scales. The second common data collection technique is interview in the studies in IJI (20\%). Similarly, this percentage is about 21\% in Gülbahar \& Alper (2009) and Y1lmaz \& Altınkurt (2012). Varışoğlu et al. (2013) points out to the scarcity of techniques such as observation and alternative tests.

In parallel with the method and data collection tools, the mostly used data analysis techniques are descriptive statistics in the studies published in IJI. The reviews by Selçuk et al. (2014); Ozan \& Köse (2014); Turan et al. (2014); Küçükoğlu \& Ozan (2013); Varışoğlu et al. (2013); Göktaş, Hasançebi et al. (2012); Şimşek et al. (2008) also found out that the mostly used data analysis techniques are descriptive statistics. Besides, they found out that t-test and ANOVA analysis are also highly resorted. These 
techniques are also found out to be the second and third most common techniques in this review $(26,2 \%)$.

The findings regarding the distribution of articles according to countries they are conducted in reveal studies from a number of countries have been published in IJI (35 countries). Tsai \& Wen (2005) reviewed articles on science education published in three international journals and found out that authors from 21, 23 and 36 countries published their articles in the reviewed journals respectively. That authors from 35 countries published their articles in IJI reveals the international aspect of the journal.

The mostly studied themes in IJI include learning, teaching, teacher education, skills, curriculum, teachers, ICT, ethics, comparative education, non-formal education and so on. These themes overlap with other journals. For instance, the themes in three international journals regarding science education include learning, teaching, teacher education, goals, policy and curriculum, culture, educational technology and informal learning (Tsai \& Wen, 2005). There is a clear overlap in themes. Similarly, in the review of Education and Science journal, Selçuk et al. (2014) listed the most common themes as curriculum and instruction, educational administration, and educational psychology. Yildiz et al. (2016) listed these as teaching methods, research methods and teacher education. Ozan \& Köse (2014) found out that teaching, student-teacher characteristics and learning are mostly studied. Master and $\mathrm{PhD}$ theses on elementary education (20082012) mostly addressed curriculum and instruction issues (Küçükoğlu \& Ozan, 2013). The most common themes in pre-service teacher education consist of characteristics of pre-service teachers, teacher education programs, instruction and information and communication technology in teacher education (Yücel-Toy (2015). On educational technology, the most common themes are learning-teaching approaches, online learning, use of multimedia and technology in education (Şimşek et al. (2008).

It can be inferred from the results that, studies in the field of education mostly employ quantitative methods, purposive or random sampling techniques, and a sample size of below 500. Data collection tools mostly consist of scales and the data are mostly analyzed using descriptive statistics. It should be substantive to suggest that there is a need for more qualitative or mixed methods to be used, more diverse sampling techniques to represent the populations studied better to be employed, and more sophisticated statistical data analysis techniques to be used. Descriptive survey designs being high in number and the most studied samples being undergraduates and teacher candidates indicate that researchers mostly prefer relatively easy to reach samples and easy to conduct research studies. This also is an indicator of a need for more complicated research designs, making it possible to understand the subject matter in depth and from different aspects and a need for studying on different samples of the stakeholders of education, making it possible to understand the phenomena of education from different points of view. IJI publishing studies from 35 different countries indicates that its level of internationality is high. For future studies, it can be suggested that, more journals or theses in the field should be analyzed via literature review studies, meta analyses or meta syntheses, so that the bigger picture of the accumulated scientific information about the field of education could be seen more clearly. 


\section{REFERENCES}

Adıgüzel, O C. \& Ergünay, O. (2012). An investigation of dissertations on values in Turkey from the perspective of educational science and teacher training. Electronic Journal of Social Sciences, 11 (41), 18-33.

APA. (2010). Publication manual of the American Psychological Association ( $6^{\text {th }}$ ed.). Washington DC: American Psychological Association.

Bozkaya, M., Aydın, İ. E. \& Kumtepe, E. G. (2012). Research trends and issues in educational technology: a content analysis of TOJET (2008-2011). The Turkish Online Journal of Educational Technology, 11 (2), 264-277.

Cohen, L., Manion, L. \& Morrison, K. (2005). Research Methods in Education. Tyler \& Francis e-Library.

Creswell, J. W. (2012). Educational research: planning, conducting, and evaluating quantitative and qualitative research (4th Ed.). Pearson: ABD.

Dunkin, M. J. (1996). Types of errors in synthesizing research in education. Review of Educational Research, 66 (2), 87-97.

Erdoğan, M., Marcinkowski, T. \& Ok, A. (2009). Content analysis of selected features of K-8 environmental education research studies in Turkey, 1997-2007. Environmental Education Research, 15 (5), 525-548.

Bowen, G. A. (2009) "Document Analysis as a Qualitative Research Method", Qualitative Research Journal, 9 (2), 27-40, doi: 10.3316/QRJ0902027

Göktaş, Y., Hasançebi, F., Varışoğlu, B., Akçay, A., Bayrak, N., Baran, M., \& Sözbilir, M. (2012). Türkiye'deki eğitim araştırmalarındaki eğilimler: bir içerik analizi [Trends in Educational Research in Turkey: A Content Analysis]. Kuram ve Uygulamada Eğitim Bilimleri. 12 (1), 443-460.

Göktaş, Y., Küçük, S., Aydemir, M., Telli, E., Arpacık, Ö., Yıldırım, G. \& Reisoğlu, İ. (2012). Educational technology research trends in Turkey: a content analysis of the 2000-2009 decade. Educational Sciences: Theory \& Practice, 12 (1), 191-196.

Gülbahar, Y. \& Alper, A. (2009). A content analysis of the studies in instructional technologies area. Ankara University Journal of Faculty of Educational Sciences, 42 (2), 93-111.

Gülmez, D. \& Yavuz, M. (2016). Eğitim liderliği ve yönetimi kapsamında 2012 yılında yayınlanmış olan makalelerin amaç ve yöntem bakımından değerlendirilmesi [The evaluation of the articles related with educational leadership and administration published in 2012 in terms of aim and method]. Elementary Education Online, 15 (2), 318-329.

Hoskyn, K., \& Zegwaard, K. E. (2015). Trends in research methods and approaches in cooperative and work-integrated education research. In 19th World Conference on Cooperative \& Work Integrated Education. Conference held in Kyoto, Japan. 
Hrastinski, S. \& Keller, C. (2007). An examination of research approaches that underlie research on educational technology: a review from 2000 to 2004. J. Educational Computing Research, 36 (2), 175-190.

Hwang, G-J. \& Tsai, C-C. (2011). Research trends in mobile and ubiquitous learning: a review of publications in selected journals from 2001 to 2010. British Journal of Educational Technology, 42 (4), E65- E70.

Karadağ, E. (2009). A thematic analysis on doctoral dissertations made in the area of education sciences. Ahi Evran Üniversitesi Eğitim Fakültesi Dergisi, 10 (3), 75-87.

Karadağ, E. (Ed.). (2015). Leadership and organizational outcomes: meta-analysis of emprical studies. Springer: Switzerland.

Keselman, H. J., Huberty, C. J., Mix, L. M., Olejnik, S., Cribbie, R. A., Donahue, B., Kowalchuk, R. K., Lowman, L. L., Petoskey, M. D., Keselman, J. C. \& Levin J. R. (1998). Statistical practices of educational researchers: an analysis of their ANOVA, MANOVA and ANCOVA analyses. Review of Educational Research, 68 (3), 350-386.

Küçük, S., Aydemir, M., Yıldırım, G., Arpacık, Ö. \& Göktaş, Y. (2013). Educational technology research trends from 1990 to 2011. Computers \& Education, 68, 42-50.

Küçükoğlu, A. \& Ozan, C. (2013). Sınıf öğretmenliği alanındaki lisansüstü tezlere yönelik bir içerik analizi [A content analysis about master theses and dissertations in classroom teacher education]. Uluslararası Avrasya Sosyal Bilimler Dergisi. 4 (12), 27 47.

Merriam, S. B. (2013). Nitel Araştırma (3. Baskıdan Çeviri Ed. Turan, S.). Ankara: Nobel Yay.

Onwuegbuzie, A. J. \& Daniel, L. G. (2003). Typology of analytical and interpretational errors in quantitative and qualitative educational research. Current Issues in Education, $6(2), 1-33$.

Ozan, C. \& Köse, E. (2014). Eğitim programları ve öğretim alanındaki araştırma eğilimleri [Research trends in Curriculum and Instruction]. Sakarya University Journal of Education, 4 (1), 116-136.

Patton, M. Q. (2002). Qualitative research \& evaluation methods (3rd Ed.). The USA: Sage Pub.

Ritchie, J \& Lewis, J. (2003). Qualitative research practice. Great Britain: Sage

Selçuk, Z., Palancı, M., Kandemir, M. \& Dündar, H. (2014). Eğitim ve bilim dergisinde yayınlanan araştırmaların eğilimleri: içerik analizi [Tendencies of researches published in education and science journal: Content analysis]. Eğitim ve Bilim, 39 (173), 430-453.

Şimşek, A., Özdamar, N., Becit, G., Kılıçer, K., Akbulut, Y. ve Yıldırım, Y. (2008). Türkiye'deki eğitim teknolojisi araştırmalarında güncel eğilimler [Current trends of educational research in Turkey]. Selçuk Üniversitesi Sosyal Bilimler Dergisi, 19, 439458. 
Tsai, C-C. \& Wen, M. L. (2005). Research and trends in science education from 1998 to 2002: a content analysis of publication in selected journals. International Journal of Science Education, 27 (1), 3-14.

Turan, S., Karadağ, E., Bektaş, F. \& Yalçın, M. (2014). Türkiye’de eğitim yönetiminde bilgi üretimi: kuram ve uygulamada eğitim yönetimi dergisi 2003-2013 yayınlarının incelenmesi [Knowledge production in educational administration in Turkey: an overview of researches in journal of educational administration: theory and practice 2003 to 2013-]. Kuram ve Uygulamada Ĕgitim Yönetimi, 20 (1), 93-119.

Varışoğlu, B., Şahin, A. \& Göktaş, Y. (2013). Türkçe eğitimi araştırmalarında eğilimler [Trends in Turkish education studies]. Educational Sciences: Theory \& Practice, 13 (3), 1767-1781.

Yıldız, N. G., Melekoğlu, M. A. \& Paftalı, A. T. (2016). Türkiye'de özel eğitim araştırmalarının incelenmesi [Special education research in Turkey]. Elementary Education Online, 15 (4), 1076-1089.

Yılmaz, K. \& Altınkurt, Y. (2012). An examination of articles published on preschool education in Turkey. Educational Sciences: Theory \& Practice. Special Issue (Autumn), 3227-3241.

Yücedağ, T. \& Erdoğan, A. (2011). Investigation of mathematics education studies according to some variables studied between 2000-2009 years in Turkey. Gaziantep Üniversitesi Sosyal Bilimler Dergisi. 10 (2), 825-838.

Yücel-Toy, B. (2015). Türkiye'deki hizmet öncesi öğretmen eğitimi araştırmalarının tematik analizi ve öğretmen eğitimi politikalarının yansımaları [Thematic analysis of pre-service teacher education studies in Turkey reflections of teacher education policies]. Eğitim ve Bilim, 40 (178), 23-60. 


\section{Turkish Abstract}

Eğitim Araştırmalarında Eğilimler: International Journal of Instruction'da Yayınlanan Araştırmaların İçerik Analizi

Bu çalışmanın amacı son on yılda International Journal of Instruction'da yayınlanan çalıșmaları [IJI] analiz etmektir. Bu çalışma nitel, tanımlayıcı bir literatür inceleme çalışmasıdır. Veriler, karşılaştırmalı analiz yapılarak kodlanmış ve içerik analizi yoluyla analiz edilmiş; analiz sonucunda frekans ve yüzdeler hesaplanmıştır. Yapılan bu çalışmada, örnekleme teknikleri, araştırma yöntemleri, istatistiksel yöntemler ve araştırmaların yapıldığı ülkeler ve bazı diğer değişkenler incelenmiştir. IJI, uluslararası, açık erişimli ve ücretsiz bir dergi olduğu için, bu analizin sonuçlarının eğitim alanında araştırma eğilimleri hakkında bir ipucu vermesi beklenmektedir.

Anahtar Kelimeler: International Journal of Instruction, araştırma eğilimleri, içerik analizi

\section{French Abstract}

Tendances dans Recherche Éducative: une Analyse de contenu des Études Publiées dans Journal International d'Instruction

Le but de cette étude est d'analyser les études publiées dans le Journal International d'Instruction [IJI] dans les dix dernières années. Cette étude est une étude d'examen qualitative, descriptive de littérature. Les données ont été rassemblées par l'analyse de document, codées utilisant la comparaison constante et analysées utilisant l'analyse de contenu. Les fréquences et les pourcentages ont été calculés. Comme IJI étant un accès international, ouvert et un journal gratuit, on attend à ce que les résultats de cette analyse donnent un indice des tendances de recherche dans le domaine de l'éducation. Au-delà de ceci, dans cette étude, les sujets, les techniques d'échantillonnage, les méthodes de recherche, les procédures statistiques et les pays dans lesquels les recherches ont eu lieu et quelques autres variables ont été examinés.

Mots Clés: Journal International d'Instruction, faites des recherches sur tendances, analyse de contenu

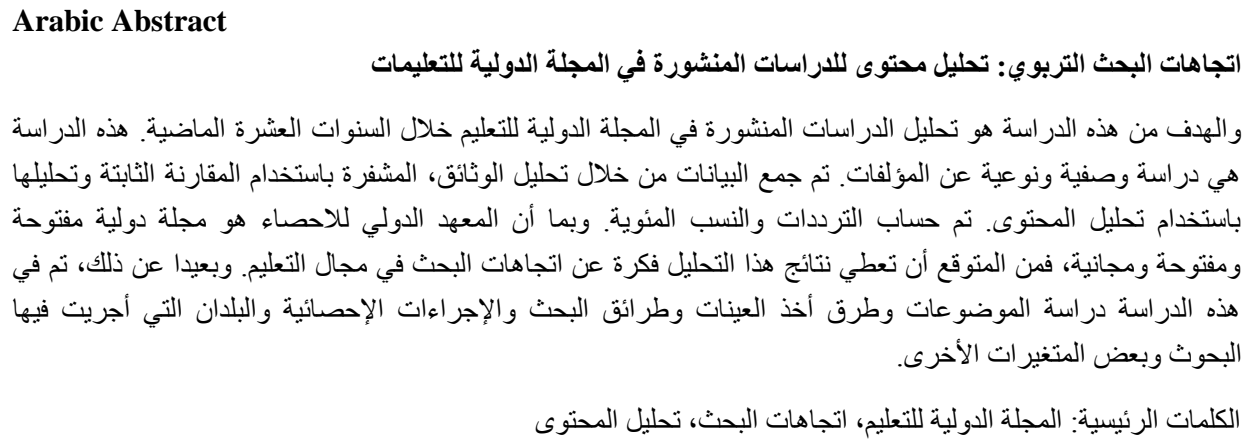

Arabic Abstract

اتجاهات البحث التربوي: تحليل محتوى للاراسات المنشورة في المجلة الدولية للتعليمات

و الهدف من هذه الدراسة هو تحليل الدراسات المنشورة في المجلة الدولية للتعليم خلال السنوات العشرة الماضية. هذه الدراسة

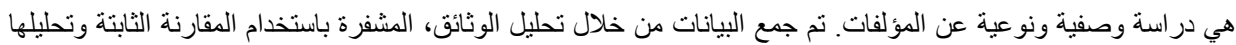

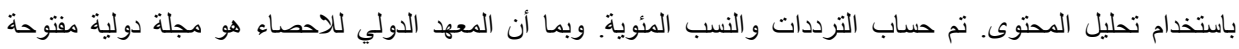

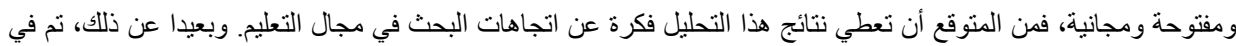

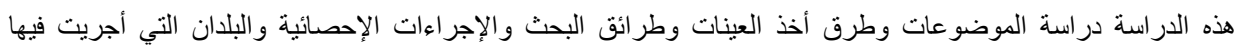
البحوث وبعض المتغيرات الأخرى. الكلمات الرئيسية: المجلة الدولية للتعليم، اتجاهات البحث، تحليل المحتوى 


\section{German Abstract \\ Trends in der Bildungsforschung: Eine Inhaltsanalyse der Studien, die in der International Journal of Instruction veröffentlicht wurden}

Das Ziel dieser Studie ist es, die in der International Journal of Instruction [IJI] veröffentlichten Studien in den letzten zehn Jahren zu analysieren. Diese Studie ist eine qualitative, deskriptive Literaturrecherche. Die Daten wurden durch Dokumentenanalyse gesammelt, mit konstantem Vergleich codiert und mittels Inhaltsanalyse analysiert. Es wurden Frequenzen und Prozentsätze berechnet. Da IJI ein internationaler, offener Zugang und eine kostenlose Zeitschrift ist, wird erwartet, dass die Ergebnisse dieser Analyse einen Hinweis auf die Forschungstrends im Bildungsbereich geben werden. Darüber hinaus wurden in dieser Studie die Themen, die Techniken der Probenahme, die Methoden der Forschung, die statistischen Verfahren und die Länder, in denen die Untersuchungen stattfanden, und einige andere Variablen untersucht.

Schlüsselwörter: Internationales Journal of Instruction, forschungstrends, inhaltsanalyse

\section{Malaysian Abstract \\ Trend Penyelidikan Pendidikan: Analisis Kandungan Pengajian yang Diterbitkan dalam Arahan Jurnal Antarabangsa}

Tujuan kajian ini adalah untuk menganalisis kajian yang diterbitkan dalam International Journal of Instruction [IJI] dalam sepuluh tahun yang lalu. kajian ini ialah, sastera deskriptif kajian, kajian kualitatif. Data yang dikumpulkan melalui analisis dokumen, dikodkan menggunakan perbandingan yang berterusan dan dianalisis menggunakan analisis kandungan. Kekerapan dan peratusan telah dikira. Sebagai Iji menjadi jurnal antarabangsa, akses terbuka dan jurnal percuma, hasil analisis ini dijangka memberi petunjuk tentang trend penyelidikan dalam bidang pendidikan. Lebih dari itu, dalam kajian ini, topik, teknik persampelan, kaedah penyelidikan, prosedur statistik dan negara-negara di mana kajian telah berlaku dan beberapa pembolehubah lain telah diperiksa.

Kata Kunci: International Journal of Instruction, trend penyelidikan, analisis kandungan

\section{Russian Abstract \\ Тенденции в Образовательных Исследованиях: Контент-Анализ Исследований, Опубликованный в Международном Журнале Обучения}

Целью этого исследования является анализ исследований, опубликованных в Международном журнале обучения [IJI] за последние десять лет. Это исследование является качественным описательным обзором литературы. Данные были собраны путем анализа документов, закодированных с использованием постоянного сравнения и проанализированы с использованием анализа контента. Рассчитаны частоты и проценты. IJI является международным, открытым и бесплатным журналом, результаты этого анализа должны дать представление о тенденциях исследований в области образования. Помимо этого, в рамках этого исследования были изучены темы, методы отбора проб, методы исследования, статистические процедуры и страны, в которых проводились исследования, и некоторые другие переменные.

Ключевые Слова: Международный Журнал Обучения, тенденции исследований, контентанализ 